KARPOV P. A. ${ }^{\otimes}$, BLUME Ya. B.

Institute of Food Biotechnology and Genomics of Natl. Acad. Sci. of Ukraine, Ukraine, 04123, Kyiv, Osypovs'koho str., $2 \mathrm{~A}$

karpov@nas.gov.ua,(050) 544-69-03

\title{
PLANT $\beta$-TUBULIN PHOSPHORYLATION ON SER172 AS CANONICAL SUPPRESSING FACTOR OF MICROTUBULE GROWTH
}

Aim. The estimation of potential role of plant $\beta$-tubulin Ser172 phosphorylation for correct function of microtubules and cell division due to selection of protein kinases, most probable associated with phosphorylation of Ser172 in Arabidopsis thaliana (L.) Heynh. Methods. Literature and database search. Comparison of protein sequences and structures: multiple sequence alignment, phylogenetic profiling, protein structure modeling, etc. Results. Comparison of Ser172 site region from all known $\beta$-tubulins from Homo sapiens, Sus scrofa, Saccharomyces cerevisiae, Drosophila melanogaster and A. thaliana confirms its significant similarity. Joint clusterization of all Ser172 site regions (in $\mathrm{S} \pm 10$ a.a. format) reveals that plant site is most similar to Ser172 \pm 10 fragment of $\beta$-tubulin from $S$. cerevisiae. At the same time, sequences and catalytic domain structures of cyclin-dependent kinases 1 and YAK1related kinases (MNB/DYRK1a/YAK1) associated with Ser172 phosphorylation, found maximal similarity in $A$. thaliana and $S$. cerevisiae. Conclusions. The results confirm similarity of amino acid environment of Ser172 in $\beta$-tubulin isotypes in human, pig, fruit fly, yeast and arabidopsis. This suggests similar effect of $\beta$-tubulin phosphorylation at Ser172 for inhibition of microtubule assembly onto their protofilaments and its association with CDK1 and YAK1-related protein kinases. Similarity of Ser172 sites and associated protein kinases, allows us to expect similar effect of this modification on structure of microtubules in A. thaliana and S. cerevisiae.

Keywords: $\beta$-tubulin, Ser172, phosphorylation, CDK1, DYRK1, MNB, YAK1.

Tubulin phosphorylation was reported in the early 1970 s by multiple research groups, and in 1972 phosphorylation of mammalian $\beta$-tubulin was documented for the first time [1-3]. One of the important $\beta$-tubulin residues is Ser172, and its phosphorylation is necessary for correct function of both cytoplasmic and spindle microtubules (MTs) and cell division [4]. Ser172 of $\beta$-tubulin is located within the S5-H5 loop, called also T5 loop [5, 6]. This site is absent in $\alpha$-tubulin, occurs within the GTP-binding domain at the interface of a $\beta$-subunit and the $\alpha$-subunit of a next heterodimer [7]. Its phosphorylation inhibits MT polymerization, likely a consequence of decreased GTP binding due to the proximity to exchangeable nucleotide-binding (GTP/GDP) site on $\beta$-tubulin [8]. Consequently, this site not only regulates GTP/GDP binding by $\beta$ tubulin, but mediates assembly of $\alpha / \beta$-heterodimers into a protofilaments as a part of the plus end MT interface $[9,10]$.

Caudron et al. (2010) reported mutations of Ser172 associated with human brain disease and its phosphorylation by the cyclin-dependent kinase Cdk1 [4]. In vitro mammalian $\beta$-tubulin can also be modified by phosphorylation at Ser172 residue by the Cdk1/cyclin B complex when heterodimer tubulin is formed. At the same time any Cdk1dependent phosphorylation of $\beta$-tubulin does not exist [6]. Phosphorylated $\beta$-tubulin or $\beta$-tubulin with a mutation mimicking permanent phosphorylation at Ser172 is either poorly, or not incorporated into MTs in vitro and in vivo. Thus, Ser172 phosphorylation may affect both GTP/GDP binding and/or turnover, and the interactions between tubulin heterodimers [6]. Also, mutations (S172A and S172) of Ser172 in yeast (Saccharomyces cerevisiae) $\beta$-tubulin (Tub2p) induce similar defects in MT dynamics and cell division [4]. Both mutants (S172A and S172E ) showed impaired cell growth on benomyl-containing mediums and at cold tem- peratures, altering in MT dynamics, nucleus posi- tioning and segregation. These findings show the importance of Ser172 for the correct function of both cytoplasmic and spindle MTs and for cell divi- sion in yeast cells [4].

Recently, it was demonstrated that minibrain (MNB)/DYRK1a kinase phosphorylates Ser172 and inhibits tubulin polymerization in neurons of Drosophila melanogaster [11]. Also, using TIRF microscopy, they imaged purified GFP-DYRKla

\footnotetext{
${ }^{\circ}$ KARPOV P. A., BLUME Ya. B.
} 
and fluorescently labeled taxol-stabilized MTs and found that GFP-DYRKla bound along MT lattice, similar to Drosophila GFP-MNB. Using kinase assay they found that GFP-DYRK1A directly phosphorylates purified porcine $\beta$-tubulin at Ser172. Finally, turbidity assays revealed that the addition of GFP-DYRKIA dramatically inhibited tubulin polymerization in an ATP-dependent manner. Together, these results indicate that the mechanisms of MT binding and tubulin phosphorylation of Ser172 are conserved between Drosophila MNB and mammalian DYRKla [11].

The purpose of this study was to compare Ser172 sites of $\beta$-tubulin isotypes in human, fruit fly, yeast and mouse-ear cress and based on these data confirm or refute conservatism of this mechanism among members of different kingdoms. Then we would like make a conclusion on the functional role of this site in higher plants and to determine plant protein kinases most likely involved in phosphorylation of Ser172 in A. thaliana.

\section{Materials and methods}

Complete amino acid sequences of the $\beta$ tubulin and protein kinases were obtained from the UniProtKB database (Protein KnowledgeBase, www.uniport.org) [12]. The search of homologous sequences was performed with the SIB BLAST Network Service and the BLASTp algorithm (BLASTP ver. 2.2.31+) [13]. Multiple alignments of the amino acid sequences were performed with the ClustalX (V.2.0.10) (www.clustal.org) software using BLOSSUM weight matrices [14]. In the case of the comparison of small polypeptide fragments of the phosphorylation sites, we applied direct comparison of the sequences in ClustalX with restriction of gaps [14]. The "Logs" of aligned sequences were created with the WebLogo3 web service [15]. Cladistic analysis of the binding sites and phylogenetic identification of the closest homologs were based on the clustering of amino acid sequences by the neighbor-joining method [16]. Visualization and analysis of dendrograms were performed with the MEGA7 software package (www.megasoftware.net) [17].

The 3D-models of protein kinases were constructed with the Swiss-Model web-service [18]. The structural model of plant cyclin-dependent kinase 1 (CDKA1_ARATH, UniProtKB: P24100) was constructed using RCSB ProteinDataBank tamplate structure 6gu7 (X-Ray diffraction, 2.75 E) of human cyclin-dependent kinase 1 [19]. The structural model of plant Cdk 1 from $S$. cerevisiae
(CDK1_YEAST, UniProtKB: P00546) was also constructed using structure 6gu7 [19]. The structural model of YAK1-related kinase (UniProtKB: Q8RWH3) from A. thaliana was taken from our previous research [20]. YAK1-related kinase from $S$. cerevisiae (YAK1_YEAST, UniProtKB: P14680) was constructed using RCSB ProteinDataBank tamplate structure 5y86 (X-Ray diffraction, $1.9 \mathrm{E})$ of human dual-specificity tyrosine-regulated kinase (DYRK) 3 [21]. Structural optimization of built models was performed in water using AMBER94 force field. Visualization and structural alignment of reconstructed models were performed with PyMOL v.1.5.0.5 (www.schrodinger.com/pymol).

\section{Results and discussions}

As it is known, Ser172 is positioned within the T5 loop, a region of $\beta$-tubulin that is in close proximity to the GTP/GDP binding site, and is part of the plus end surface that mediates the assembly of the heterodimers into a protofilament $[9,10]$. Based on this information and sequence similarity, we extracted fragments (S172 10$)$ of all known $\beta$ tubulin isotypes from $H$. sapiens, $S$. scrofa, $S$. cerevisiae, D. melanogaster and A. thaliana. Despite strict conservatism of Ser172 and significant sequence similarity, some intra- and interspecies differences in the amino acid environment of this site are evident (Fig. 1). Since the main purpose of our research was to evaluate the potential functional role of Ser172 phosphorylation in plants, on next step we determined the sites that are most similar to the last one in A. thaliana among homologous (control) sequences from $H$. sapiens, $S$. scrofa, S. cerevisiae and D. melanogaster. For this purpose joint clustering of above-mentioned sequences from $\beta$ tubulin isotypes of $A$. thaliana and appropriate control group from human, pig, fruit fly and yeast was performed. As it is represented on the Fig. 2, fragments from A. thaliana form a separate and compact group. This confirms similarity of Ser172 site in all $\beta$-tubulins of $A$. thaliana. At the same time, the group of these sequences demonstrates higher similarity to $\beta$-tubulin fragment from $S$. cerevisiae, than to the sequences from $H$. sapiens, S. scrofa, and D. melanogaster.

To date, CDK1 and DYRK1A have been shown to phosphorylate Ser172 to regulate MT growth during the cell cycle and neuronal morphogenesis, respectively $[6,11,22]$. Based on literature, information from UniProtKB and sequence homology, we identified appropriate cyclin- 
dependent kinases 1 (CDK1) and Dual specificity YAK1-related kinases (Dyrk1/Dyrk1A/MNB/ Yak1) from $H$. sapiens, S. cerevisiae, D. melanogaster and A. thaliana (Table). Usually clusterization of protein kinases is based on sequence similarity in their kinase domains [23]. The clustering of the catalytic domains of selected cyclindependent kinases 1 (Fig. 3a) and dual specificity YAK1-related kinases (Fig. 3b) reveal maximum similarity in the case of protein kinases from A. thaliana and S. cerevisiae (Fig. 3).

Subsequent 3D-modeling of catalytic domains, and their structural alignment (after structure optimization with AMBER94 force field), reveal significant similarity of appropriate 3D-structures of cyclin-dependent and YAK1-related kinases from A. thaliana and S. cerevisiae (Fig. 4a, b). In the case of cyclin-dependent kinases 1 (Fig. 4a), the index of RMS was 0.763, and in the case of dual specificity of YAK1-related kinases, the index of RMS was 0.585 (Fig. 4b), this is significantly less than the threshold value (RMS=1) and fully corresponds to the results of our visual assessment. Thus, we can assert a high similarity of compared spatial structures.
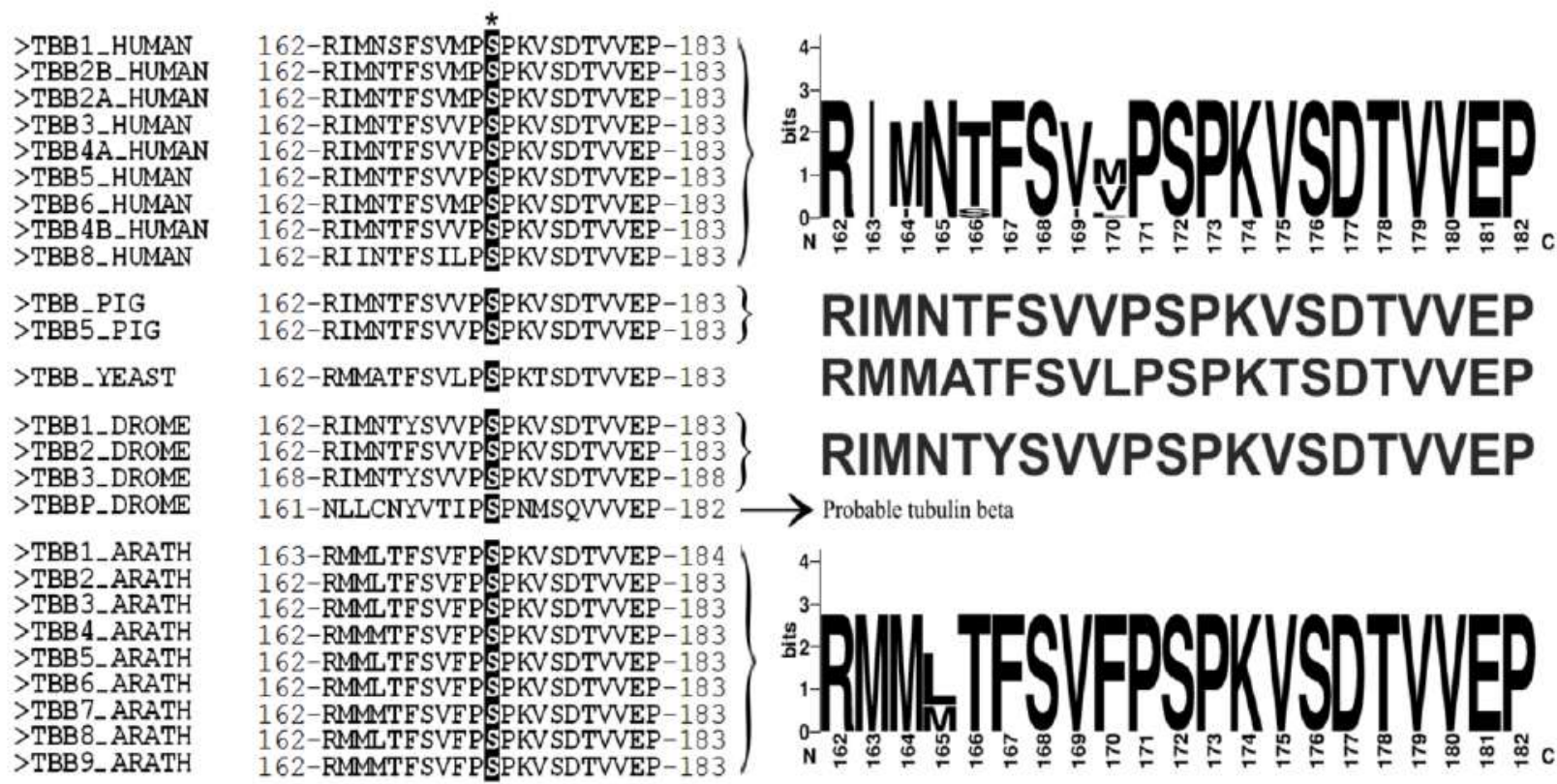

RIMNTFSVVPSPKVSDTVVEP RMMATFSVLPSPKTSDTVVEP RIMNTYSVVPSPKVSDTVVEP $>$ Probable tubulin beta
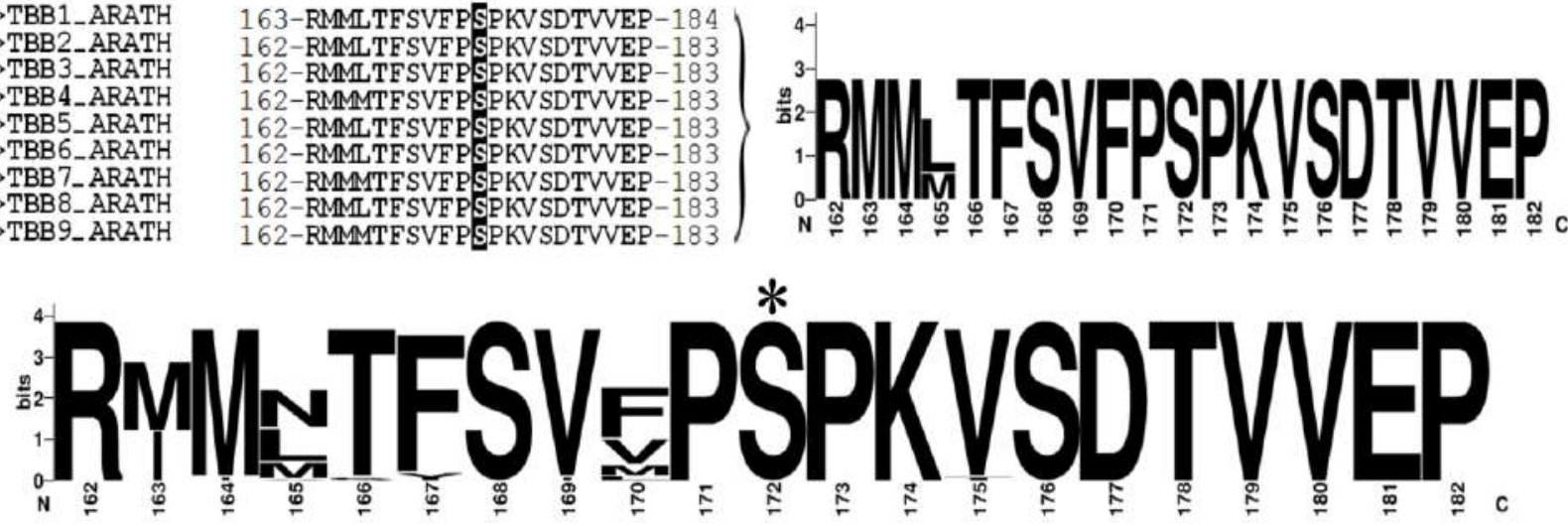

Fig. 1. Similarity of Ser172 regions in $\beta$-tubulins from H. sapiens (HUMAN), S. scrofa (PIG), S. cerevisiae (YEAST), D. melanogaster (DROME) and A. thaliana (ARA TH). Resulting "Log" sum up all represented sites, excepting atypical sequence TBBP_DROME of probable $\beta$-tubulin from $D$. melanogaster.

Table. Cyclin-dependent kinases 1 (CDK1) and dual specificity YAK1-related kinases associated with phosphorylation of $\beta$-tubulin on Ser172 (based on experimental data and prediction)

\begin{tabular}{|l|c|c|c|}
\hline \multicolumn{1}{|c|}{ Species } & CDK1 & Dyrk1A/MNB/Yak1 & Source of information \\
\hline H. sapiens & CDK1 (P06493) & Dyrk1* (Q13627) & $\begin{array}{c}\text { [6] (for CDK1), } \\
{[11] \text { (for Dyrk1) }}\end{array}$ \\
\hline S. cerevisiae & CDK1 (P00546) & YAK1 (P14680) & $\begin{array}{c}\text { [4] indirect evidence for CDK1 } \\
\text { and prediction for YAK1 }\end{array}$ \\
\hline D. melanogaster & CDK1 (P23572) & MNB (P49657) & $\begin{array}{c}\text { predicted (for CDK1), } \\
{[11] \text { (for MNB) }}\end{array}$ \\
\hline A. thaliana & CDKA1 (P24100) & YAK1 (Q8RWH3) & prediction \\
\hline
\end{tabular}

Note. * based on homology with the Dyrk1/MNB kinase from pig (S. scrofa, UniProtKB: I3L9V1). 


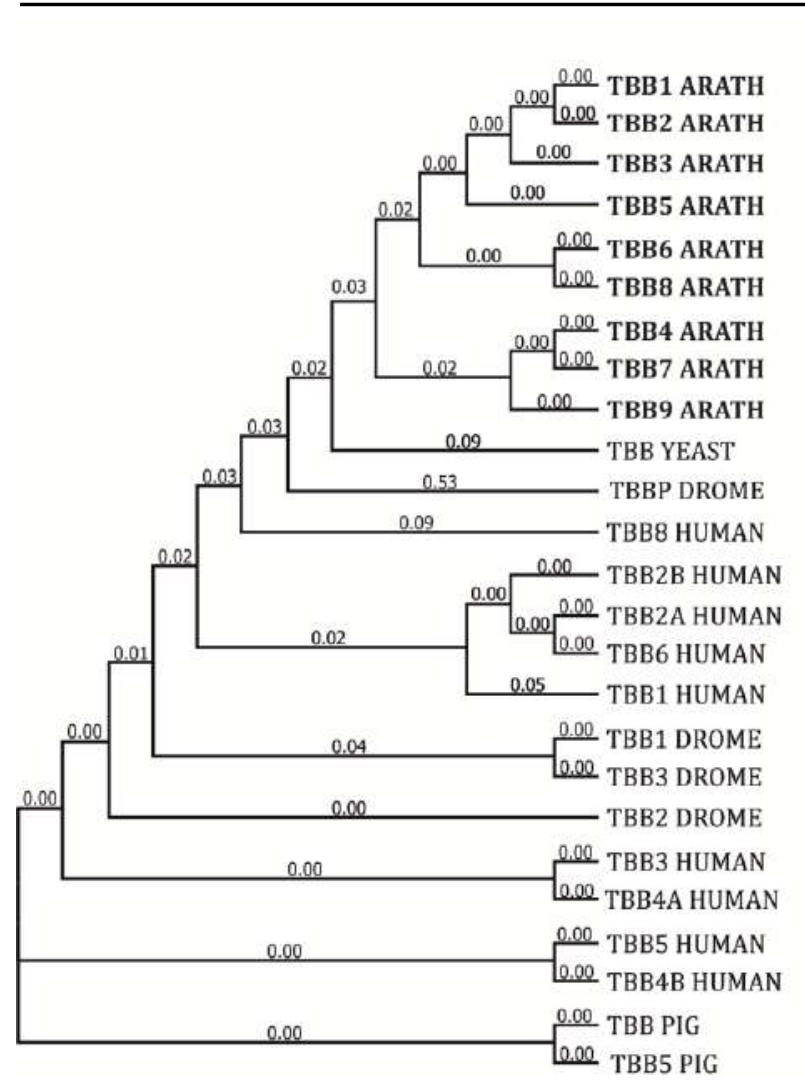

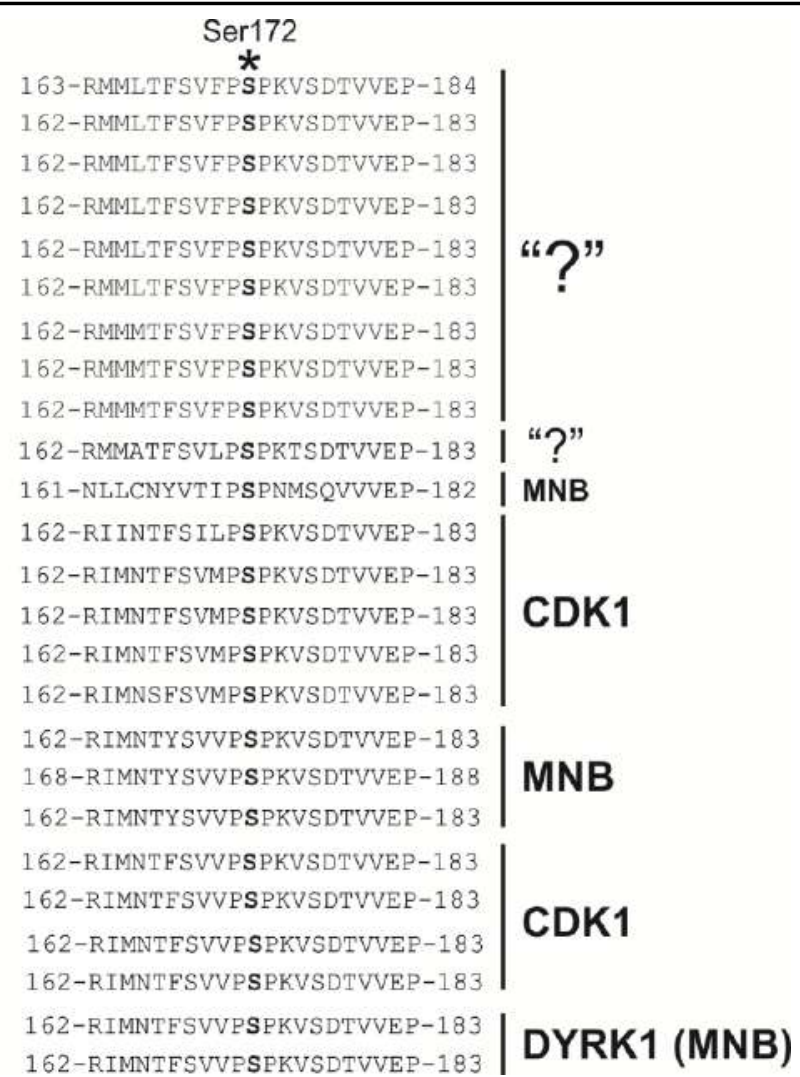

Fig. 2. Joint clusterization of Ser172 regions of $\beta$-tubulin isotypes from H. sapiens (HUMAN), S. scrofa (PIG), S. cerevisiae (YE AST), D. melanogaster (DRO ME ) and A. thaliana (ARATH).

Note: On the right, the names of protein kinases, which phosphorylate compared site in accordance with experimental data $[6,11]$ or bioinformatic evidences are marked.

a)

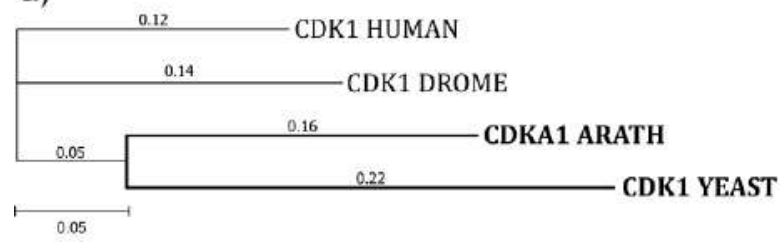

b)

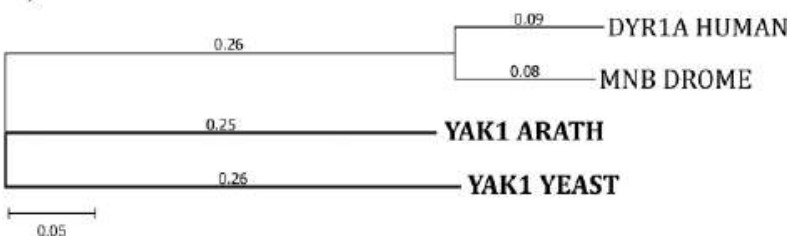

Fig. 3. Results of NJ-clusterization of kinase domains from cyclin-dependent kinases 1 (a) and YAK1-related kinases (MNB/DYRK1A/YAK1) (b) from H. sapiens (HUMAN), S. cerevisiae (YEAST), D. melanogaster (DROME) and A. thaliana (ARATH).

\section{Conclusions}

This study confirms conservatism and similar function of $\beta$-tubulin phosphorylation on Ser172 in mammals, insects, fungi, and higher plants. We suppose that in all studied species, phosphorylation of $\beta$-tubulin at Ser172 inhibits $\alpha / \beta$-tubulin heterodimer assembling into MT protofilaments. In addition, similarity in phosphorylation site (Ser172) and in associated with it cyclin-dependent kinases 1 and YAK1-related kinases suggests maximum similarity of such regulation in A. thaliana and $S$. cerevisiae. This allows us to consider $S$. cerevisiae as the most suitable system for further genetic transformation and platform for confirmation of the role of plant CDK1 and YAK1 in MT assembling. 


\section{CDK1/CDKA1}

a)

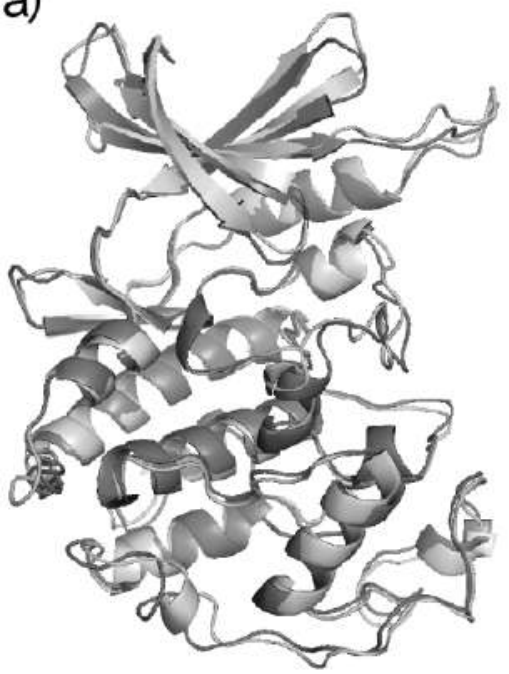

RMS $=0,763$

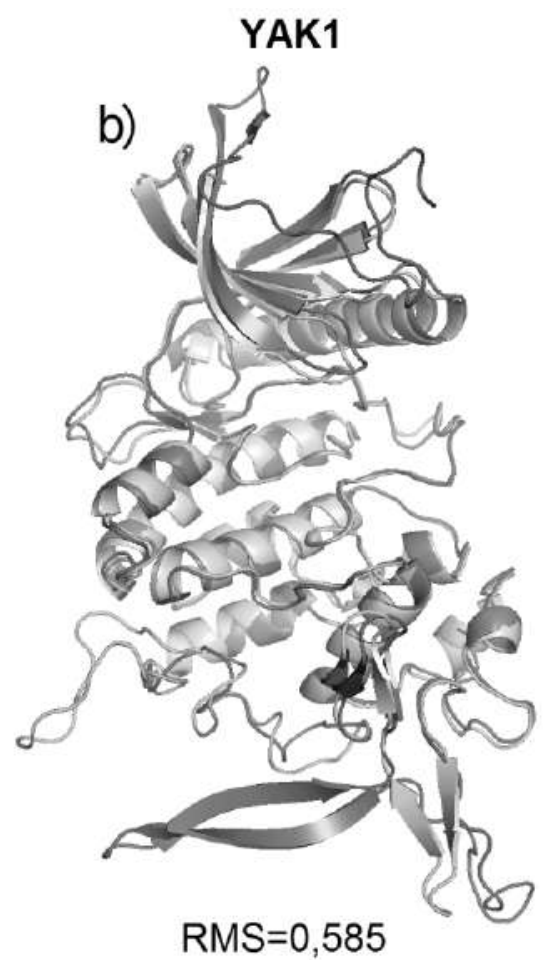

Fig. 4. Results of structural comparison of kinase domains from cyclin-dependent kinases 1 (a) and dual specificity YAK1-related kinases (b) from A. thaliana (green color / dark grey) and S. cerevisiae (beige color / light gray).

\section{References}

1. Goodman D.P.B., Rasmussen H., DiBella F., Guthrow C.E. Jr. Cyclic adenosine 3',5'-monophosphate-stimulated phosphorylation of isolated neurotubule subunits. Proc. Natl. Acad. Sci. USA. 1970. Vol. 67. P. 652-659.

2. Murray A.W., Froscio M. Cyclic adenosine $3^{\prime}: 5^{\prime}$-monophosphate and microtubule function: specific interaction of the phosphorylated protein subunits with a soluble brain component. Biochem. Biophys. Res. Commun. 1971. Vol. 44. P. 1089-1095.

3. Eipper B.A. Rat brain microtubule protein: purification and determination of covalently bound phosphate and carbohydrate. Proc. Natl. Acad. Sci. USA. 1972. Vol. 69. P. 2283-2287.

4. Caudron F., Denarier E., Thibout-Quintana J.C., Brocard J., Andrieux A., Fourest-Lieuvin A. Mutation of Ser172 in yeast $\beta$-tubulin induces defects in microtubule dynamics and cell division. PLoS One. 2010. Vol. 5 (10). e13553. doi: 10.1371/journal.pone.0013553.

5. Wloga D., Joachimiak E., Fabczak H. Tubulin post-translational modifications and microtubule dynamics. Int. J. Mol. Sci. 2017. Vol. 18 (10). P. 2207. doi: 10.3390/ijms18102207.

6. Fourest-Lieuvin A., Peris L., Gache V., Garcia-Saez I., Juillan-Binard C., Lantez V., Job D. Microtubule regulation in mitosis: tubulin phosphorylation by the cyclin-dependent kinase Cdk1. Mol. Biol. Cell. 2006. Vol. 17. P. 1041-1050. doi: 10.1091/mbc.e05-07-0621.

7. Abeyweera T.P., Chen X., Rotenberg S.A. Phosphorylation of $\alpha 6$-tubulin by protein kinase C $\alpha$ activates motility of human breast cells. J. Biol. Chem. 2009. Vol. 284 (26). P. 17648-17656. doi: 10.1074/jbc.M902005200.

8. Yu I., Garnham C.P., Roll-Mecak A. Writing and reading the tubulin code. J. Biol. Chem. 2015. Vol. 290 (28). P. 1716317172. doi: 10.1074/jbc.R115.637447.

9. Nogales E., Whittaker M., Milligan R.A., Downing K.H. High-resolution model of the microtubule. Cell. 1999. Vol. 96. P. 7988. doi: 10.1016/S0092-8674(00)80961-7.

10. Inclán Y.F., Nogales E. Structural models for the self-assembly and microtubule interactions of $\gamma$-, $\delta$ - and $\varepsilon$-tubulin $J$. Cell Sci. 2001. Vol. 114 (Pt 2). P. 413-422.

11. Ori-McKenney K.M., McKenney R.J., Huang H.H., Li T., Meltzer S., Jan L.Y., Vale R.D., Wiita A.P., Jan Y.N. Phosphorylation of $\beta$-tubulin by the down syndrome kinase, minibrain/DYRK1a, regulates microtubule dynamics and dendrite morphogenesis. Neuron. 2016. Vol. 90 (3). P. 551-563. doi: 10.1016/j.neuron.2016.03.027.

12. The UniProt Consortium. UniProt: the universal protein knowledgebase. Nucl. Acids Res. 2018. Vol. 46 (5). P. 2699. doi: 10.1093/nar/gky092.

13. Lee M.M., Chan M.K., Bundschuh R. SIB-BLAST: a web server for improved delineation of true and false positives in PSIBLAST searches. Nucl. Acids Res. 2009. Vol. 37 (1-2). W53-W56. doi: 10.1093/nar/gkp301.

14. Larkin M.A., Blackshields G., Brown N.P., Chenna R., McGettigan P.A., McWilliam H., Valentin F., Wallace I.M., Wilm A., Lopez R., Thompson J.D., Gibson T.J., Higgins D.G. Clustal W and Clustal X. version 2.0. Bioinformatics. 2007. Vol. 23 (21). P. 2947-2948. doi: 10.1093/bioinformatics/btm404. 
15. Crooks G.E., Hon G., Chandonia J.M., Brenner S.E. WebLogo: A sequence logo generator. Genome Res. 2004. Vol. 14 (6). P. 1188-1190. doi: 10.1101/gr.849004.

16. Atteson K. The performance of neighbor-joining algorithms of phylogeny reconstruction. Lecture Notes Comp. Sci. 1997. Vol. 1276. P. 101-110.

17. Kumar S., Stecher G., Tamura K. MEGA7: Molecular evolutionary genetics analysis version 7.0 for bigger datasets. Mol. Biol. Evol. 2016. Vol. 33 (7). P. 1870-1874. doi: 10.1093/molbev/msw054.

18. Waterhouse A., Bertoni M., Bienert S., Studer G., Tauriello G., Gumienny R., Heer F.T., de Beer T.A.P., Rempfer C., Bordoli L., Lepore R., Schwede T. SWISS-MODEL: homology modeling of protein structures and complexes. Nucl. Acids Res. 2018. Vol. 46 (W1). W296-W303. doi: 10.1093/nar/gky427.

19. Wood D.J., Korolchuk S., Tatum N.J., Wang L.Z., Endicott J.A., Noble M., Martin M.P. Differences in the conformational energy landscape of CDK1 and CDK2 suggest a mechanism for achieving selective CDK inhibition. Cell Chem. Biol. 2019. Vol. 26 (1). P. 121-130. e5. doi: 10.1016/j.chembiol.2018.10.015.

20. Karpov P., Raevsky A., Korablyov M., Blume Ya. Identification of plant homologues of Dual Specificity Yak1-Related Kinases. Comput. Biol. J. 2014. Vol. 12 (ID 909268). P. 1-14. doi: 10.1155/2014/909268.

21. Kim K., Cha J.S., Cho Y.S., Kim H., Chang N., Kim H.J., Cho H.S. Crystal structure of human Dual-specificity TyrosineRegulated Kinase 3 reveals new structural features and insights into its auto-phosphorylation. J. Mol. Biol. 2018. Vol. 430 (10). P. 1521-1530. doi: 10.1016/j.jmb.2018.04.001.

22. Ramkumar A., Jong B.Y., Ori-McKenney K.M. ReMAPping the microtubule landscape: how phosphorylation dictates the activities of microtubule-associated proteins. Dev. Dyn. 2018. Vol. 247 (1). P. 138-155. doi: 10.1002/dvdy.24599

23. Duong-Ly K.C., Peterson J.R. The human kinome and kinase inhibition. Curr. Protoc. Pharmacol. 2013. Chapter 2. Unit 2.9. doi: 10.1002/0471141755.ph0209s60.

КАРПОВ П. А., БЛЮМ Я. Б.

Державна установа «Інститут харчової біотехнологї та геноміки НАН України», Україна, 04123, м. Київ, вул. Осиповського, 2 а

\section{ФОСФОРИЛЮВАННЯ РОСЛИННОГО НИЧНОЇ СУПРЕССИВНОЇ РЕГУЛЯЦІї РОСТУ МІКРОТРУБОЧОК}

Mema. Оцінити потенційне значення фосфорилювання рослинного $\beta$-тубуліну за залишком Ser172 для коректного функціонування мікротрубочок і нормального поділу клітин. Відібрати рослинні протеїнкінази, що найбільш ймовірно пов'язані з фосфорилюванням Ser172 у Arabidopsis thaliana (L.) Heynh. Memoдu. Аналіз літератури і пошук в базах даних. Біоінформатичне порівняння послідовностей білків та їх структур. Множинні вирівнювання послідовностей, філогенетичне профілювання, моделювання структури білка тощо. Результати. Біоінформатичне порівняння ділянки сайту Ser172 з усіх відомих ізотипів $\beta$-тубуліну з Homo sapiens, Sus scrofa, Saccharomyces cerevisiae, Drosophila melanogaster та A. thaliana підтвердило їх значну подібність. Спільна кластеризація усіх ділянок Ser172 (у форматі $\mathrm{S} \pm 10$ а.а.) визначила найбільшу подібність рослинного сайту до Ser172 \pm 10 фрагмента $\beta$-тубуліну з S. cerevisiae. Водночас, послідовності та структури каталітичних доменів Cyclin-dependent kinases 1 i YAK1-related kinases (MNB / DYRK1a / YAK1), що пов'язані з фосфорилюванням Ser172, визначають найбільшу подібність у випадку A. thaliana i S. cerevisiae. Висновки. Отримані результати підтверджують подібність амінокислотного оточення Ser172 в ізотипах $\beta$-тубуліну людини, свині, плодової мушки, дріжджів і арабідопсису. Це свідчить про аналогічне інгібування збірки протофіламентів мікротрубочок унаслідок фосфорилювання $\beta$-тубуліну за залишком Ser172 та його залежність від активності CDK1 і YAK1подібних протеїнкіназ. Подібність ділянок сайту Ser172 та асоційованих з ними протеїнкіназ дозволяє очікувати аналогічний ефект від впливу цієї модифікації на мікротрубочки у A. thaliana та S. cerevisiae.

Ключові слова: $\beta$-тубулін, Ser172, фосфорилювання, CDK1, DYRK1, MNB, YAK1. 